\title{
Female partner preferences enhance offspring ability to survive an infection
}

\author{
Shirley Raveh ${ }^{1,2^{*}}$, Sanja Sutalo ${ }^{1}$, Kerstin E Thonhauser ${ }^{1}$, Michaela Thoß ${ }^{1}$, Attila Hettyey ${ }^{1,3}$, Friederike Winkelser ${ }^{1}$ \\ and Dustin J Penn ${ }^{1}$
}

\begin{abstract}
Background: It is often suggested that mate choice enhances offspring immune resistance to infectious diseases. To test this hypothesis, we conducted a study with wild-derived house mice (Mus musculus musculus) in which females were experimentally mated either with their preferred or non-preferred male, and their offspring were infected with a mouse pathogen, Salmonella enterica (serovar Typhimurium).
\end{abstract}

Results: We found that offspring sired by preferred males were significantly more likely to survive the experimental infection compared to those sired by non-preferred males. We found no significant differences in the pathogen clearance or infection dynamics between the infected mice, suggesting that offspring from preferred males were better able to cope with infection and had improved tolerance rather than immune resistance.

Conclusion: Our results provide the first direct experimental evidence within a single study that partner preferences enhance offspring resistance to infectious diseases.

Keywords: Partner preference, Sexual selection, Mus musculus musculus, Salmonella, Pathogen clearance, Disease resistance, Pathogen-mediated sexual selection, Tolerance

\section{Background}

Mating preferences are widespread and can function to confer indirect, genetic benefits for offspring [1-3]. Direct evidence for genetic benefits from mate choice come from studies that compare the fitness of offspring from females (experimentally) mated with preferred $(\mathrm{P})$ versus nonpreferred (NP) males (experimental sexual selection) [4-6]. For example, it has been shown that peahens (Pavo cristatus) had increased reproductive success when mated with P males [7,8]. Similarly, in house mice (Mus musculus domesticus) offspring sired by females' $\mathrm{P}$ males had higher survival compared to offspring sired by NP males [9]. However, it remains unclear how mate choice enhances offspring survival. Since there is much genetic variation influencing immune resistance to infection [10-12], it has been suggested that mate choice may provide genetic

\footnotetext{
* Correspondence: shirley.raveh@unibas.ch

'Konrad Lorenz Institute of Ethology, Department of Integrative Biology and Evolution, University of Veterinary Medicine Vienna, Savoyenstr. 1a, 1160 Vienna, Austria

${ }^{2}$ Present address: Department of Environmental Sciences Zoology and Evolution, University of Basel, Vesalgasse 1, 4051 Basel, Switzerland Full list of author information is available at the end of the article
}

benefits that enhance offspring resistance against infectious diseases (Hamilton-Zuk hypothesis) [13-15].

Since Hamilton and Zuk's [13] classic paper, numerous studies have found that males with more parasites or weak immune responses have reduced secondary sexual traits compared to other males [16,17], and that females show preference for healthy versus experimentally parasitized males. For example, in house mice, males produce scent marks, which are attractive to females, and females are able to recognize and show preferences for the scent of healthy, uninfected versus experimentally infected males [18-21]. Such preferences may provide direct benefits (lower risk of disease transmission or increased paternal care) or indirect, genetic benefits $[22,23]$. For example, a study with stickleback fish (Gasterosteus aculeatus) found that offspring sired by more brightly coloured males were less likely to become infected after an experimental exposure to cestode larvae compared to duller males (though offspring of brightly coloured males also grew more slowly, they did not mount higher immune responses and they did not have improved hatching or post-hatch survival compared to dull males) [24]. Yet, there have been no studies to our 
knowledge that have experimentally tested whether female choice enhances offspring resistance to infectious diseases within a single study.

We conducted a study with wild-derived house mice (Mus musculus musculus) to test whether female preferences enhance offspring's resistance to an experimental challenge of Salmonella enterica (serovar Typhimurium). Several genes control resistance to Salmonella in mice, which include MHC (major histocompatibility complex) [25], SLC11A1 (Ity/Lsh/Bcg/N-ramp1), and toll-like receptor 4 (Tlr4) [26-28]. After testing females' preferences for individual males in dyadic 'partner preference' experiments, we mated females to either their P or NP males. The offspring of these pairings were experimentally infected with a mouse pathogen (Salmonella enterica) to assess their ability to resolve infection over three weeks (pathogen clearance). We expected that offspring sired by $\mathrm{P}$ males would have lower pathogen burdens (or loads) and enhanced survival compared to those sired by NP males. In addition, females can potentially enhance offspring survival due to differential maternal investment into offspring sired by high quality males (differential allocation hypothesis) [29-31]. Alternatively, it has been suggested that females should invest more into offspring when mating with low-quality males and enhance offspring body mass and survival (reproductive compensation hypothesis) [30,32-34]. Therefore, we also tested whether offspring from $\mathrm{P}$ sires had greater body mass compared to those from NP males.

\section{Results}

\section{Reproduction}

After the experimental matings with $\mathrm{P}$ or NP males, most females $(83 \%)$ produced litters and females mated with a P male were more likely to produce a litter (14 litters from 15 pairings or $93 \%$ success) compared to females mated with NP males (11 litters from 15 pairings or $73 \%)$, though this difference was not significant $\left(x^{2}=\right.$ $2.08, \mathrm{df}=1, \mathrm{p}=0.165)$. Females mated with $\mathrm{P}$ males produced significantly larger litters (mean $\pm \mathrm{SE}=7.2 \pm 0.5$ ) than those mated with NP males (mean $\pm \mathrm{SE}=6.3 \pm 0.8$ ) $\left(\mathrm{df}=1, \mathrm{~F}_{1,12}=5.54, \mathrm{p}=0.036\right)$. In addition, heavier females produced larger litters than lighter dams $(\mathrm{df}=1$, $\mathrm{F}_{1,12}=5.48, \mathrm{p}=0.037$; range: 2 to 11 offspring per litter). The interaction between sire treatment ( $P$ or NP) and dam body mass was non-significant $\left(\mathrm{df}=1, \mathrm{~F}_{1}, 11=0.91\right.$, $P=0.656)$. No evidence was found to suggest that mean offspring body mass was affected by pairing dams with $\mathrm{P}$ or NP males $\left(F_{1,11}=0.30, \mathrm{p}=0.594\right)$ or female body mass ( $\left.F_{1,11}=0.16, P=0.696\right)$, and the two-way interaction between partner preference and female weight was non-significant $\left(F_{1,11}=0.23, p=0.641\right)$. Pairing females with $\mathrm{P}$ males resulted in more male offspring compared to NP pairings and heavier females produced more sons compared to lighter females (pairing with $\mathrm{P}$ or NP male: Wald $\chi^{2}=4.89, \mathrm{df}=1, \mathrm{p}=0.027$; female weight: Wald $\chi^{2}=10.96, \mathrm{df}=1, \mathrm{p}=0.001$; interaction: Wald $\chi^{2}=1.54, \mathrm{df}=1, \mathrm{p}=0.214$ ).

\section{Offspring survival}

We challenged offspring with an experimental Salmonella infection and we found that 73\% (53/72) of offspring survived the infection until euthanasia, and offspring sired by $\mathrm{P}$ males had higher survival than those of NP males ( $p=0.0088$, Table 1 ). Survival of offspring sired by NP, but not by $\mathrm{P}$ males decreased over time, as shown by the significant interaction between the partner preference treatment ( $P$ vs. NP) and week $(p=0.0016$, Table 1 ; Figure 1). Female offspring $(n=31)$ had better survival than male offspring $(n=22)$ regardless of the partner preference (Table 1; Figure 2). The main effects of body mass, week, and all remaining two-way interactions did not affect survival (Table 1). Body mass of animals of $\mathrm{P}$ and NP sires used in the infection experiment did not differ significantly $\left(F_{1,68}=2.66 ; \mathrm{p}=0.11\right)$ or across weeks $\left(F_{1,68}=0.22 ; \mathrm{p}=0.64\right)$, yet males were heavier than females (males: 21.29 $\pm 0.54 \mathrm{~g}$ (mean $\pm \mathrm{SE}$ ); females: $\left.18.95 \pm 0.34 \mathrm{~g} ; F_{1,69}=15.36 ; \mathrm{p}<0.001\right)$. All two-way interactions were non-significant (all $\mathrm{p}>0.15$ ).

\section{Offspring pathogen clearance}

The overall pathogen load was unrelated to partner preference $(\mathrm{P} / \mathrm{NP})$, duration of infection (week), or sex (LMM, partner preference: $F_{1,35}=0.77, \mathrm{p}=0.38$; sex: $F_{1,10}=0.05$, $\mathrm{p}=0.81$; week: $\left.F_{1,10}=1.27 ; \mathrm{p}=0.28\right)$. All two-way interactions remained non-significant (all p $>0.1$ ).

Table 1 Table 1 Effects of partner preference (P/NP), sex, week (1-3), and body mass on survival as calculated with starting date of the experiments and family ID as random effects using generalized linear mixed-effects modelling procedures

\begin{tabular}{lccc}
\hline & df & F & $\boldsymbol{P}$ \\
\hline Partner preference & 40 & 7.595 & $0.0088^{* *}$ \\
Sex & 26 & 12.569 & $0.0015^{* *}$ \\
Week & 26 & 0.202 & 0.6565 \\
Lgbodymass & 25 & 0.101 & 0.7537 \\
Partner preference ${ }^{\times}$week & 26 & 10.801 & $0.0029^{* *}$ \\
Sex $^{\times}$partner preference & 24 & 2.510 & 0.1262 \\
Sex $^{\times}$week & 20 & 0.003 & 0.9545 \\
Sex $^{\times}$Igbodymass & 21 & 0.008 & 0.9298 \\
Partner preference $^{\times}$Igbodymass & 23 & 0.444 & 0.5118 \\
Week $^{\times}$Igbodymass & 21 & 0.062 & 0.8060 \\
\hline
\end{tabular}

**: $P<0.01$.

$\mathrm{x}$ : interaction between two variables. 


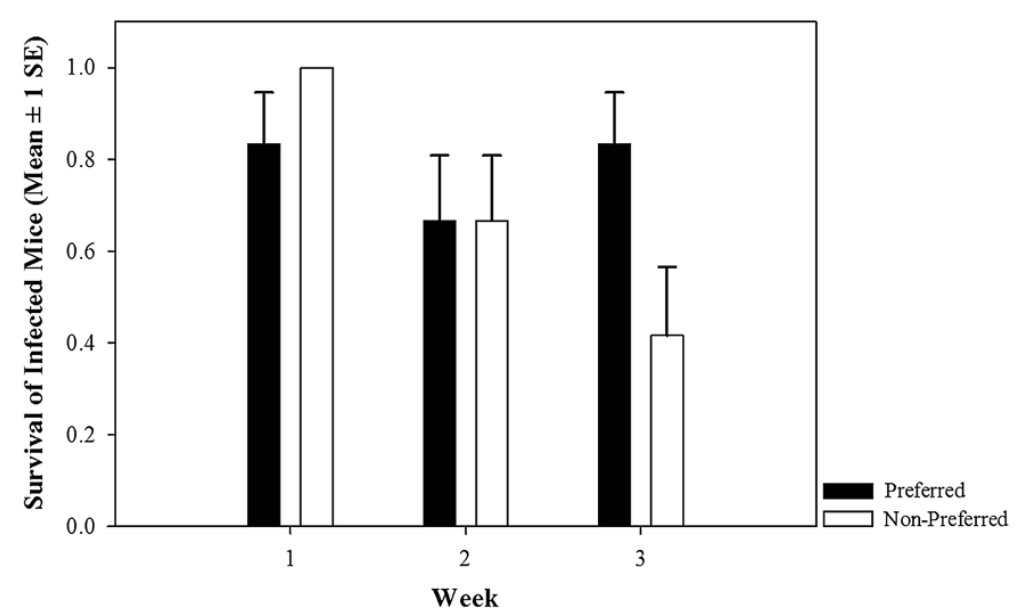

Figure 1 Proportion of individuals that survived the experimental infection over the course of three weeks. Black bars represent offspring sired by $P$ and white bars sired by NP males. A significant interaction between partner preference treatment ( $P$ vs. NP) and week was found: survival between offspring from $P$ and NP sires emerged three weeks after inoculation, with an enhanced survival of offspring sired by $P$ males compared to young sired by NP males (see Table 1).

\section{Discussion}

We found that females experimentally mated to P males produced significantly more offspring (larger litters) than those mated to NP males, which confirms that nonrandom partner preferences confer fitness benefits [9]. Furthermore, we found that offspring sired by P males were significantly more likely to survive the experimental Salmonella infection than those sired by NP males. The difference in survival between offspring from $\mathrm{P}$ and NP sires emerged three weeks after inoculation, which

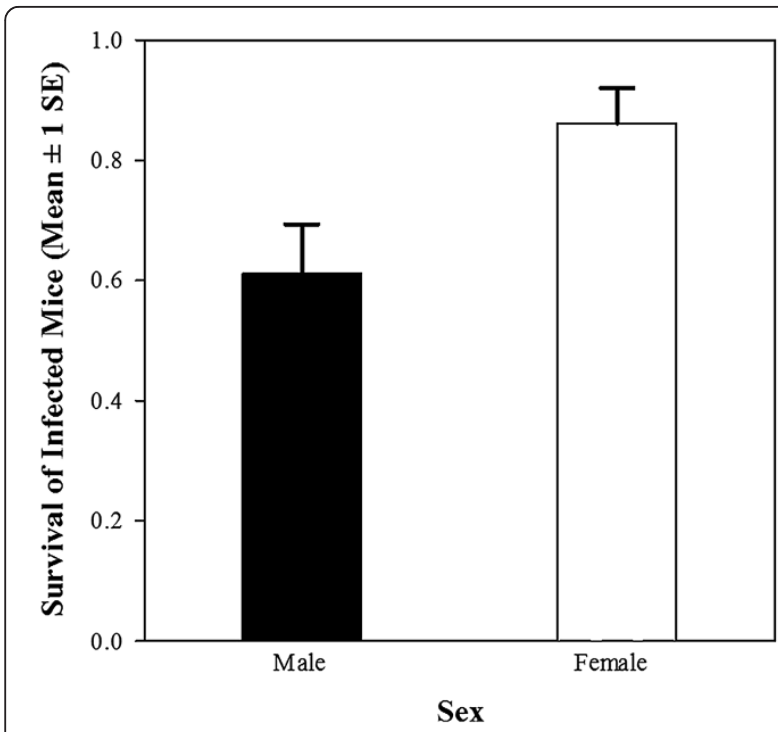

Figure 2 Sex-dependent survival for females and males after the experimental infection. Female offspring $(n=31$, white bar) had an enhanced survival compared to male offspring ( $n=22$, black bar) regardless of the partner preference (see Table 1). Error bars represent standard error of the mean. corresponds precisely to the peak of Salmonella growth in the spleen of house mice [35]. We are confident that the differences in survival was due to the experimental infection because sham-infected mice never die in our experience $[21,25,36]$, and the other offspring from our experimental matings, which were not experimentally infected $(N=108)$, all survived the three-week experiment. Our findings are consistent with a previous study that found outbred house mice are more likely to survive Salmonella infection than inbred mice [37]. Thus, our results support the hypothesis that female preferences can enhance offspring ability to survive infection.

The enhanced survival of offspring from $P$ versus NP sires could have been due to differences in their ability to control pathogen burden ('pathogen clearance' or 'immune resistance') or their capacity to cope with or limit the damage caused by a given pathogen burden ('disease resistance' or 'tolerance') [38-40], or both. We found that pathogen loads did not differ between treatments, which suggest that female preferences enhanced tolerance to infection rather than immune resistance per se. However, as we were unable to assess the pathogen loads of the mice that died during the experiment, we cannot rule out possible benefits from controlling pathogen growth. Previous sexual selection (and ecoimmunology) studies have mainly measured immune responses to novel antigens (immunocompetence) or observed parasite burdens, but our findings emphasize the importance of using functional challenges with real pathogens and measuring hosts' ability to cope with infection (health and survival) $[20,38,41]$. Otherwise, measuring only resistance to infection will fail to detect many important aspects of host defences, such as immunoregulation, which functions to minimize damage from immunopathology ('optimal 
immunocompetence' [20] or 'optimal immunity') [42-44]. Studies are needed to determine whether tolerance - like resistance to infection - is heritable [45,46], conditiondependent [47-50] and influences the expression of secondary sexual traits (e.g., scent or ultrasonic vocalizations in house mice). It is likely that females are able to obtain tolerant and disease resistant offspring by preferring males in overall good condition (rather than recognizing males with strong immune resistance per se) [44,51], as expected by the genic capture hypothesis $[52,53]$.

The enhanced survival of offspring sired by P males may have been due to genetic effects, maternal allocation, or both. This benefit was potentially genetic, as it has been found that outbred mice have better survival following Salmonella infection compared to inbred (from sib-sib matings) mice [37]. Since neither litter size nor the offspring weight differed between $\mathrm{P}$ versus NP sires, we found no evidence for differential maternal allocation, though we cannot rule out this potential mechanism. We also found that females mated to $\mathrm{P}$ males produced more sons than those mated to NP males, though this bias in offspring sex-ratio could have been due to maternal or paternal effects. Heavier females produced significantly more sons than lighter females, suggesting offspring sex ratio depends on females' condition, as predicted by the Trivers and Willard hypothesis [54]. Yet, differences in litter size and offspring sex ratio do not explain why $\mathrm{P}$ offspring had better survival compared to NP offspring, and therefore, it is more likely that this difference we found was due to genetic influences to disease resistance [28]. Further studies are needed to test whether genetic effects or differential maternal allocation can explain the variation in offspring survival after an infection.

Finally, female offspring had better survival following Salmonella infection compared to males, and as we found no sex differences in pathogen clearance, this result also appears to have been due to sex differences in tolerance to infection (this finding was not influenced by higher production of daughters by females mated with NP males, as animals were evenly allocated for partner preference and sex). Females generally have increased resistance to pathogens and parasites compared to males [55-57], and another study found that female mice showed lower Salmonella prevalence compared to males following experimental infection [37]. Such sex differences may be due to testosterone or other steroid hormones [58-60]. For example, it has been reported that estrogen administration in females resulted in a higher susceptibility to Salmonella typhimurium, whereas progesterone enhanced resistance to infection [61], though these findings are controversial [62]. Future studies are needed to compare sex differences in tolerance to Salmonella infection, and the underlying mechanisms, especially in wild or outbred house mice.

\section{Conclusions}

Our findings provide the first direct experimental evidence to our knowledge that partner preferences enhance offspring survival following infection. We found no evidence that the offspring from preferred sires had more effective pathogen clearance than offspring from non-preferred sires, suggesting mate choice may enhance the ability to cope with infection (tolerance rather than pathogen resistance per se). Future studies are needed to investigate this hypothesis, and especially the underlying developmental mechanisms controlling tolerance to infection, both genetic and environmental maternal effects. Our results and the rapidly growing research on measuring tolerance to infection should inspire renewed interest on pathogen-mediated and sexual selection.

\section{Methods}

\section{Study system}

The mice used in this experiment were F2 descendants of wild-trapped house mice (Mus musculus musculus) from Vienna ( $48^{\circ} 12^{\prime} 38^{\prime \prime} \mathrm{N}$; $16^{\circ} 16^{\prime} 54^{\prime \prime}$ E). The parental generation were trapped at 14 different locations within a $500 \mathrm{~m}$ radius and then bred between locations. F1 mice were tested in a social partner preference and either a female's preferred $(\mathrm{P})$ or the non-preferred (NP) male was assessed and paired accordingly (see below) [following 9]. The resulting offspring (F2 generation) were used for experimental infection (see below). All F2 mice were weaned at the age of $21 \pm 1$ days and were kept individually in standard mouse cages $(26.5 \times 20.7 \times$ $14 \mathrm{~cm}$ ) with wooden bedding (Abedd: aspen wood chips), enrichment material consisting of nesting material (Abedd: aspen wood shavings), and nest boxes. Food (Altromin rodent diet 1324) and water were provided ad libitum. A standard 12:12 h light cycle was maintained and temperature ranged from 22 to $25^{\circ} \mathrm{C}$. After experimental infection animals were housed individually in ventilated cages $(36.5 \times 20.7 \times 14 \mathrm{~cm}$, IVC). All other housing conditions remained identical to conditions prior to infection.

\section{Social preference test}

To test partner preference in wild-derived house mice, F1 mice were assigned to 30 triplets each containing one female $(N=30)$ and two unrelated males $(N=60)$. Prior to the social preference test, all females successfully mated and raised one litter to avoid any confounds from females' sexual experience. Males were sexually mature $(16.52 \pm 0.35$, mean $\pm \mathrm{SE})$, however they had no mating experience. On the day of the experiment, all mice were weighed. Mice were brought to the testing room at 12:00 to allow the animals to acclimate for six hours (five triplets were tested per day). During acclimation, 
male mice were stimulated with $5 \mu \mathrm{l}$ of pooled female's urine on filter paper (collected and mixed from seven females over five consecutive days). The experiments started in the dark phase (under red light conditions) and were conducted between 18:00 and 22:00. All trials were recorded with a D-link camera (DCS-3710 Day \& Night WDR network camera) sensitive to red light. To avoid any effects from the presence of an observer on mouse behavior all experiments were simultaneously observed outside the experimental room on a monitor connected to the video camera system. Later, recorded videos were analyzed using the program Noldus Observer XD 9.0 to verify initial partner preference of females based on direct monitor observations.

The experimental apparatus consisted of three cages (Figure 3): one central female cage $(26.5 \times 20.5 \times 14 \mathrm{~cm})$ was connected with plastic tubes to two male cages on the left and right side, each measuring $36.5 \times 20.5 \times$ $14 \mathrm{~cm}$ (Figure 3). Male cages were separated into two compartments (i, ii) using an acrylic glass divider with several holes. This setup allowed exchange of acoustic, tactile and odour signals, however prevented mating. First, at the beginning of the experiment males were placed individually into their compartments (i), and bedding material from the male's original cage was scattered in the other compartment (ii) of the male cages to provide direct odour cues for the female (Figure 3).
Afterwards females were placed in the central cage. The connecting tubes were closed with regular inflated balloons to prevent the female from 1) entering male cages until the habituation period for all animals ended and 2) obtaining odour cues from male's bedding material before the experiment started. After 10 minutes of acclimatization, video recording started and the balloons were simultaneously deflated to make the tubes (and cages) accessible for the female. The female was considered to have entered or left a cage when its nose was visible in the cage. The social preference recording began once the female had visited both male cages. This procedure ensured that the female was aware of both males (when she left the second male's cage). Each trial lasted for 10 minutes, which has been shown to be a good predictor for partner preference [9]. Time the female had spent in each male cage was recorded by using a stopwatch. A male was classified as 'preferred' if the female spend more than $60 \%$ of the time in its compartment [following 9]. Subsequently, half of the females were paired with their preferred $(\mathrm{P})$, the other half with their non-preferred (NP) male in a new cage and returned to their housing room. Females that were paired with $\mathrm{P}$ or NP males did not differ in weight (Mann-Whitney $U$ test: $\mathrm{U}=43, \mathrm{P}=0.631, \mathrm{r}=0.11$ ). All pairs were separated after five days. The litter sizes, individual F2-pup weight and sex ratio were determined at weaning.

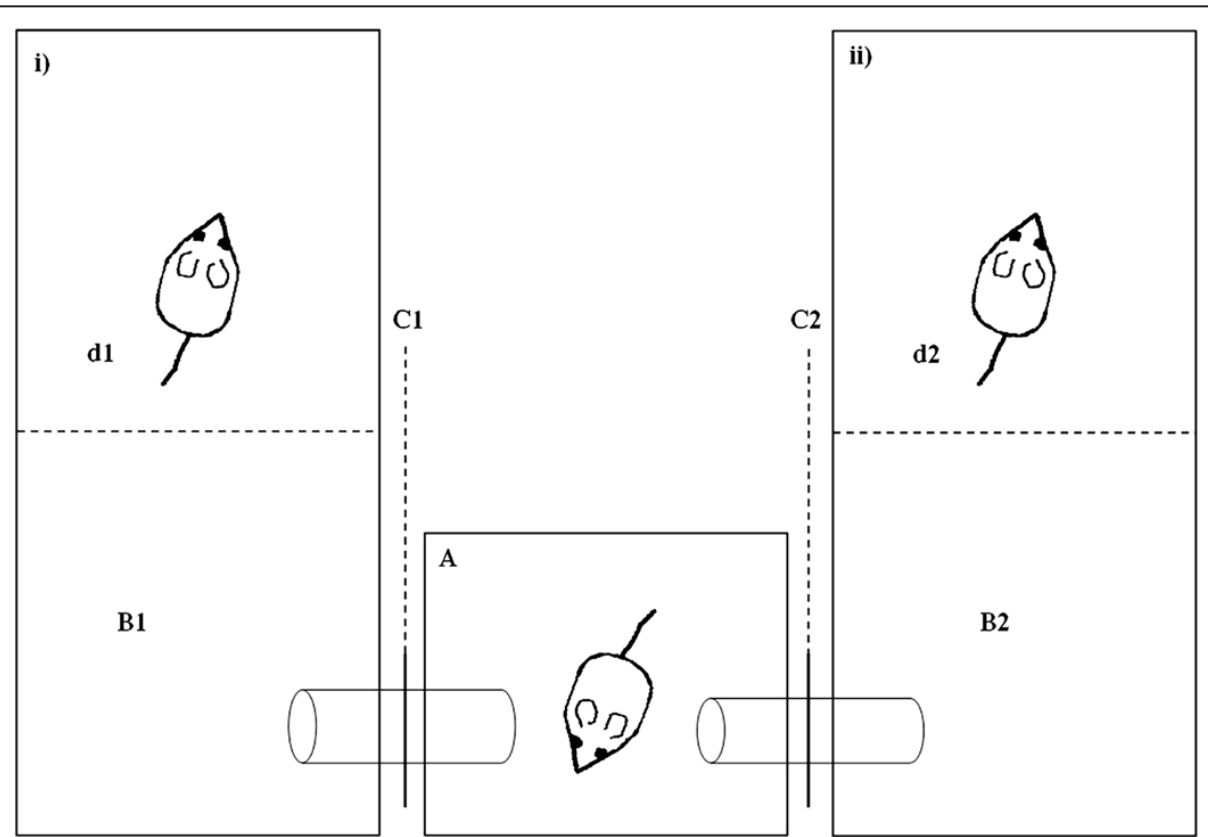

Figure 3 Social preference test. The central cage (A), where the female was located, was connected with the two male cages (B1, B2) by plastic tubes. The tubes were closed at the beginning of the experiment, after acclimatization the barriers were removed (C) to enable females (A) to access the two males' cages. Males cages were separated into two compartments using perforated plastic dividers (d1), d2), which allowed olfactory, acoustic and visual inspection between sexes, however preventing a mating event. Each male was restrained to only one compartment of their cage (i, ii). 


\section{Salmonella infection}

To assess pathogen clearance of F2 offspring from P versus NP sires, a total of 72 offspring resulting from 23 families were experimentally infected on two consecutive days. The number of individuals was balanced for partner preference (P/NP) and sex. All mice were adults (1521 weeks old) and received an intraperitoneal (IP) infection of $200 \mu \mathrm{l}$ Salmonella enterica serovar Typhimurium $\left(10^{3} \mathrm{cfu} \mathrm{mL}^{-1}\right.$, strain LT2). The bacteria (stored as slants at $4^{\circ} \mathrm{C}$ and originated from frozen stocks at $-80^{\circ} \mathrm{C}$ ) were cultured in $7.5 \mathrm{ml}$ of heart-brain infusion at $37^{\circ} \mathrm{C}$ for $13 \mathrm{~h}$ (overnight) while shaking at $170 \mathrm{rpm}$. The overnight solution was diluted with sterile phosphate buffered saline (PBS) until the desired dilution of $10^{3}$. To verify the concentration, serial plating of the dilution $(50 \mu \mathrm{l}$ per plate and three plates per solution) was performed.

All animals $(\mathrm{N}=72)$ were divided into three groups to obtain a sample size of 24 individuals per week during the experimental period of three weeks. Groups were balanced for partner preference and sex. Individuals were euthanized and dissected over three weeks: group 1 after seven days $(\mathrm{N}=24)$, group 2 after 14 days $(\mathrm{N}=24)$, and group 321 days post infection $(\mathrm{N}=24)$. The health condition of mice was examined daily until the end of the experiment. All animals were weighed weekly and euthanized humanely using an overdose of $\mathrm{CO}_{2}$. Additionally, we also monitored the survival of additional $\mathrm{P}$ $(\mathrm{N}=64)$ and $\mathrm{NP}(\mathrm{N}=44)$ offspring in the colony (same age class), which were not experimentally infected. To determine pathogen loads of experimentally infected animals, spleens of euthanized animals were immediately removed and homogenized (Dispergierstation, $\mathrm{T}$ 8.10, $\mathrm{IKA}^{\oplus}$-Werke) in $1 \mathrm{ml}$ PBS under sterile conditions. Afterwards, $50 \mu \mathrm{l}$ of each homogenate was plated on selective agar plates (Önöz Salmonella agar Merck, Darmstadt, Germany), and incubated overnight for 18 hours at $36^{\circ} \mathrm{C}$. Pathogen loads per spleen were determined by calculating bacterial concentration (cfu/spleen) of spleen homogenates [25,37] using the mean of three replicate plates. The experimental procedure was in accordance with ethical standards and guidelines in the care and use of experimental animals of the Ethical and Animal Welfare Commission of the University of Veterinary Medicine Vienna (Permit No. BMWF-68.205/ 0261-II/3b/2011).

\section{Statistical analyses}

To assess differences in female reproductive success when paired with $P$ versus NP we compared the number of litters produced in the different treatments using a $\chi^{2}$ test. Differences in litter sizes were analysed using a general linear model (GLM) with pairing ( $P$ or NP male) as a fixed factor and female body mass as a covariate. Mean pup weight (offspring quality) was calculated as the total weight of litters divides by litter size at weaning. We compared mean pup weight of litters sired from $\mathrm{P}$ versus NP males in using a GLM with pairing ( $\mathrm{P}$ or NP male) as a fixed factor and female body mass as a covariate. Sex ratio was analysed using a generalized linear model (GZLM) with a binomial distribution and a logit link function. The number of males within a litter was included as the dependant variable and litter size as binomial denominator. Pairing (P or NP male) was integrated as a fixed factor and female body mass as a covariate. These statistical analyses were performed using IBM SPSS ${ }^{\bullet}$ version 19 (SPSS Inc., Chicago, Illinois) software.

For subsequent pathogen and survival models we tested whether initial body mass was randomly distributed across experimental groups by using a linear mixed-effects model (LMM) with offspring sex and partner preference (P, NP) as fixed effects and week (time to euthanasia, see above) as a covariate. We also entered the day of experimental infection as a random effect to control for statistical nonindependence of trials started on one or the other date. Additionally, to control for sex difference in body mass, we calculated residuals of body mass on sex and used these residuals as sex-independent measure of body mass. We transformed individual body mass and count data (pathogen load) using log-transformation to enhance normality and homogeneity of variances.

To assess individual pathogen load, we applied a LMM, entering partner preference (P/NP), and sex as fixed effects, week as a covariate and starting date of the experiments and family $(\mathrm{N}=23)$ as random effects. We analysed survival using a generalized linear mixed-effects model (GZLMM) with binomial error distribution, entering partner preference treatment, and sex as fixed effects, week and body mass as covariates and starting date of the experiments and family ID as random effects. Statistical analyses were performed using ' $R$ ' (version 2.14.1). We implemented LMMs using the 'Ime' function of the 'nlme' package, and GZLMM using the 'glmmPQL' function of the 'MASS' package.

We included all two-way interactions into initial models and applied a backward stepwise removal procedure [63] to avoid problems because of inclusion of non-significant terms $(\mathrm{P}<0.05)$ [64]. Removed variables were re-entered one by one to the final model to obtain relevant statistics.

Competing interests

The authors declare that they have no competing interests.

Authors' contributions

SR and DJP designed the study, SR, SS, KET, MT and FW collected the data, $\mathrm{SR}$ and $\mathrm{AH}$ performed the analysis. All authors contributed towards writing the manuscript and approved its final version.

\section{Acknowledgments}

This study was funded by the Austrian Academy of Sciences, Austrian Science Fund (FWF P 24711-B21) to D.J. Penn, a Swiss National Science Foundation fellowship to S. Raveh (PBNEP3-132801 and PBNEP3-140190), and 
A. Hettyey was supported by the "Lendület" program of the Hungarian Academy of Sciences (MTA, LP2012-24/2012). We are grateful to H. Sasse and M. Krakhofer for the maintenance of mice, and G. Munimanda for the help with microbiology. L.C. Drickamer, P. Ilmonen, M. Kölliker provided insightful comments on earlier drafts of this manuscript.

\section{Author details}

${ }^{1}$ Konrad Lorenz Institute of Ethology, Department of Integrative Biology and Evolution, University of Veterinary Medicine Vienna, Savoyenstr. 1a, 1160 Vienna, Austria. ${ }^{2}$ Present address: Department of Environmental Sciences Zoology and Evolution, University of Basel, Vesalgasse 1, 4051 Basel, Switzerland. "Present address: "Lendület" Evolutionary Ecology Research Group, Plant Protection Institute, Centre for Agricultural Research, Hungarian Academy of Sciences, Herman Ottó út 15, 1022 Budapest, Hungary.

Received: 11 October 2013 Accepted: 2 January 2014

Published: 23 January 2014

\section{References}

1. Clutton-Brock T, McAuliffe K: Female mate choice in mammals. Q Rev Biol 2009, 84:3-27.

2. Jennions MD, Petrie M: Why do females mate multiply? A review of the genetic benefits. Biol Rev 2000, 75:21-64.

3. Zeh JA, Zeh DW: Reproductive mode and the genetic benefits of polyandry. Anim Behav 2001, 61:1051-1063.

4. Hettyey A, Hegyi G, Puurtinen M, Hoi H, Török J, Penn DJ: Mate choice for genetic benefits: time to put the pieces together. Ethology 2010, 116:1-9. 10.1111/j.1439-0310.2009.01704.x.

5. Jennions MD, Kahn A, Kelly C, Kokko H: Meta-analysis and sexual selection: past studies and future possibilities. Evol Ecol 2012, 26:1119-1151. 10.1007/s10682-012-9567-1.

6. Kotiaho JS, Puurtinen M: Mate choice for indirect genetic benefits: scrutiny of the current paradigm. Funct Ecol 2007, 21:638-644. 10.1111/j.1365-2435.2007.01286.x.

7. Petrie $M$, Williams A: Peahens lay more eggs for peacocks with larger trains. Proc R Soc Lond B Biol Sci 1993, 251:127-131.

8. Petrie $M$, Halliday $T$, Sanders $C$ : Peahens prefer peacocks with elaborate trains. Anim Behav 1991, 41:323-331.

9. Drickamer LC, Gowaty PA, Holmes CM: Free female mate choice in house mice affects reproductive success and offspring viability and performance. Anim Behav 2000, 59:371-378. 10.1006/anbe.1999.1316.

10. Malo D, Skamene E: Genetic control of host resistance to infection. Trends Genet 1994, 10:365-371.

11. Hill AVS: The immunogenetics of human infectious diseases. Annu Rev Immunol 1998, 16:593-617.

12. Hurst LD, Smith NG: Do essential genes evolve slowly? Curr Biol 1999 9:747-750.

13. Hamilton WD, Zuk M: Heritable true fitness and bright birds: a role for parasites? Science 1982, 218:384-386.

14. Folstad I, Karter AJ: Parasites, bright males, and the immunocompetence handicap. Am Nat 1992, 139:603-622.

15. Penn D, Potts $W$ : The evolution of mating preferences and major histocompatibility genes. Am Nat 1999, 153:145-164. 10.1086/303166.

16. Møller AP, Christe P, Lux E: Parasitism, host immune function, and sexual selection. Q Rev Biol 1999, 74(74):20-73.

17. Hamilton WJ, Poulin R: The Hamilton and Zuk hypothesis revisited: a meta-analytical approach. Behaviour 1997, 134:299-320.

18. Kavaliers M, Choleris E, Pfaff DW: Genes, odours and the recognition of parasitized individuals by rodents. Trends Parasitol 2005, 21:423-429.

19. Ehman KD, Scott M: Female mice mate preferentially with non-parasitized males. Parasitology 2002, 125:461-466. 10.1017\}5003118200200224X

20. Penn D, Potts WK: Chemical signals and parasite-mediated sexual selection. Trends Ecol Evol 1998, 13:391-396. 10.1016/S0169-5347(98)01473-6.

21. Zala SM, Potts WK, Penn DJ: Scent-marking displays provide honest signals of health and infection. Behav Ecol 2004, 15:338-344. 10.1093/beheco/arh022.

22. Johnsen A, Andersen V, Sunding C, Lifjeld JT: Female bluethroats enhance offspring immunocompetence through extra-pair copulations. Nature 2000, 406:296-299.

23. Penn DJ: The scent of genetic compatibility: sexual selection and the major histocompatibility complex. Ethology 2002, 108:1-21. 10.1046/j.1439-0310.2002.00768.x.
24. Barber I, Arnott SA, Braithwaite VA, Andrew J, Huntingford FA: Indirect fitness consequences of mate choice in sticklebacks: offspring of brighter males grow slowly but resist parasitic infections. Proc $R$ Soc Lond B Biol Sci 2001, 268:71-76. 10.1098/rspb.2000.1331.

25. Penn DJ, Damjanovich K, Potts WK: MHC heterozygosity confers a selective advantage against multiple-strain infections. Proc Natl Acad Sci USA 2002, 99:11260-11264. 10.1073/pnas.162006499.

26. Caron J, Loredo-Osti J, Laroche L, Skamene E, Morgan K, Malo D: Identification of genetic loci controlling bacterial clearance in experimental Salmonella enteritidis infection: an unexpected role of Nramp1 (Slc11a1) in the persistence of infection in mice. Genes Immun 2002, 3:196-204.

27. Mathur R, Oh H, Zhang D, Park SG, Seo J, Koblansky A, Hayden MS, Ghosh S: A mouse model of Salmonella typhi infection. Cell 2012, 151:590-602.

28. Roy MF, Malo D: Genetic regulation of host responses to Salmonella infection in mice. Genes Immun 2002, 3:381-393.

29. Burley N: The differential allocation hypothesis: an experimental test. Am Nat 1988, 132:612-628.

30. Harris WE, Uller T: Reproductive investment when mate quality varies: differential allocation versus reproductive compensation. Philos Trans $R$ Soc Lond B Biol Sci 2009, 364:1039-1048.

31. Sheldon BC: Differential allocation: tests, mechanisms and implications. Trends Ecol Evol 2000, 15:397-401.

32. Bluhm CK, Gowaty PA: Reproductive compensation for offspring viability deficits by female mallards, Anas platyrhynchos. Anim Behav 2004, 68:985-992.

33. Gowaty PA, Drickamer LC, Schmid-Holmes S: Male house mice produce fewer offspring with lower viability and poorer performance when mated with females they do not prefer. Anim Behav 2003, 65:95-103. 10.1006/anbe.2002.2026.

34. Gowaty PA, Anderson WW, Bluhm CK, Drickamer LC, Kim YK, Moore AJ: The hypothesis of reproductive compensation and its assumptions about mate preferences and offspring viability. Proc Natl Acad Sci USA 2007, 104:15023-15027. 10.1073/pnas.0706622104.

35. Johanns TM, Ertelt JM, Rowe JH, Way SS: Regulatory T cell suppressive potency dictates the balance between bacterial proliferation and clearance during persistent Salmonella infection. PLoS pathogens 2010, 6:e1001043.

36. Ilmonen P, Penn DJ, Damjanovich K, Morrison L, Ghotbi L, Potts WK: Major histocompatibility complex heterozygosity reduces fitness in experimentally infected mice. Genetics 2007, 176:2501-2508. 10.1534/genetics.107.074815.

37. Ilmonen P, Penn DJ, Damjanovich K, Clarke J, Lamborn D, Morrison L, Ghotbi L, Potts WK: Experimental infection magnifies inbreeding depression in house mice. J Evol Biol 2008, 21:834-841. 10.1111/j.1420-9101.2008.01510.x.

38. Schneider DS, Ayres JS: Two ways to survive infection: what resistance and tolerance can teach us about treating infectious diseases. Nat Rev Immunol 2008, 8:889-895. 10.1038/Nri2432.

39. Read AF, Graham AL, Råberg L: Animal defenses against infectious agents: is damage control more important than pathogen control. PLoS biology 2008, 6:e1000004.

40. Medzhitov R, Schneider DS, Soares MP: Disease tolerance as a defense strategy. Science 2012, 335:936-941.

41. Zala S, Potts W, Penn DJ: Exposing males to female scent increases the cost of controlling Salmonella infection in wild house mice. Behav Ecol Sociobiol 2008, 62:895-900. 10.1007/s00265-007-0513-0.

42. Råberg L, Grahn M, Hasselquist D, Svensson E: On the adaptive significance of stress-induced immunosuppression. Proc R Soc Lond $B$ 1998, 265:1637-1641.

43. Viney ME, Riley EM, Buchanan KL: Optimal immune responses: immunocompetence revisited. Trends Ecol Evol 2005, 20:665-669.

44. Westneat $D$, Birkhead T: Alternative hypotheses linking the immune system and mate choice for good genes. Proc R Soc Lond B Biol Sci 1998, 265:1065-1073. 10.1098/rspb.1996.0041 1471-2954.

45. Blanchet S, Rey O, Loot G: Evidence for host variation in parasite tolerance in a wild fish population. Evol Ecol Res 2010, 24:1129-1139.

46. Råberg L, Sim D, Read AF: Disentangling genetic variation for resistance and tolerance to infectious diseases in animals. Science 2007, 318:812-814. 10.1126/science.1148526.

47. Hõrak P, Tegelmann L, Ots I, Møller AP: Immune function and survival of great tit nestlings in relation to growth conditions. Oecologia 1999, 121:316-322. 
48. Ilmonen $\mathrm{P}$, Hakkarainen $\mathrm{H}$, Koivunen $\mathrm{V}$, Korpimäki E, Mullie A, Shutler D: Parental effort and blood parasitism in Tengmalm's owl: effects of natural and experimental variation in food abundance. Oikos 1999, 86:79-86.

49. Moret $Y$, Schmid-Hempel P: Survival for immunity: the price of immune system activation for bumblebee workers. Science 2000, 290:1166-1168.

50. Merilä J, Andersson MS: Reproductive effort and success are related to haematozoan infections in blue tits. Ecoscience 1999, 6:421-428.

51. Adamo SA, Spiteri RJ: He's healthy, but will he survive the plague? Possible constraints on mate choice for disease resistance. Anim Behav 2009, 77:67-78.

52. Rowe $L$, Houle $D$ : The lek paradox and the capture of genetic variance by condition dependent traits. Proc R Soc Lond B Biol Sci 1996, 263:1415-1421.

53. Lorch PD, Proul $\times$ S, Rowe L, Day T: Condition-dependent sexual selection can accelerate adaptation. Evol Ecol Res 2003, 5:867-881.

54. Trivers RL, Willard DE: Natural selection of parental ability to vary sex-ratio of offspring. Science 1973, 179:90-92. 10.1126/science.179.4068.90.

55. Medina E, Goldmann O, Rohde M, Lengeling A, Chhatwals GS: Genetic control of susceptibility to group A streptococcal infection in mice. $J$ Infect Dis 2001, 184:846-852. 10.1086/323292.

56. Poulin R, Forbes MR: Meta-analysis and research on host-parasite interactions: past and future. Evol Ecol 2012, 26:1169-1185.

57. Greenblatt $\mathrm{HC}$, Diggs $\mathrm{CL}$, Rosenstreich DL: Trypanosoma rhodesiense: analysis of the genetic control of resistance among mice. Infect Immun 1984, 44:107.

58. Grossman CJ: Interactions between the gonadal steroids and the immune system. Science 1985, 227:257-261.

59. Duckworth RA, Mendonca MT, Hill GE: A condition dependent link between testosterone and disease resistance in the house finch. Proc R Soc Lond B 2001, 268:2467-2472.

60. Roberts ML, Buchanan KL, Evans MR: Testing the immunocompetence handicap hypothesis: a review of the evidence. Anim Behav 2004, 68:227-239. 10.1016/j.anbehav.2004.05.001.

61. Kita EY, Yagyu Y, Nishikawa F, Hamuro A, Oku D, Emoto M, Katsui N, Kashiba S: Alterations of host resistance to mouse typhoid infection by sex hormones. J Leukoc Biol 1989, 46:538-546.

62. García-Gómez E, González-Pedrajo B, Camacho-Arroyo I: Role of sex steroid hormones in bacterial-host interactions. BioMed Res Int 2013, 2013:10. 928290.

63. Grafen A, Hails R: Modern statistics for the life sciences. New York: Oxford University Press; 2002.

64. Engqvist $L$ : The mistreatment of covariate interaction terms in linear model analyses of behavioural and evolutionary ecology studies. Anim Behav 2005, 70:967-971.

doi:10.1186/1471-2148-14-14

Cite this article as: Raveh et al:: Female partner preferences enhance offspring ability to survive an infection. BMC Evolutionary Biology 2014 14:14.

\section{Submit your next manuscript to BioMed Central and take full advantage of:}

- Convenient online submission

- Thorough peer review

- No space constraints or color figure charges

- Immediate publication on acceptance

- Inclusion in PubMed, CAS, Scopus and Google Scholar

- Research which is freely available for redistribution 